March 18, 2011

\title{
Austin's Home Performance with Energy Star Program: Making a Compelling Offer to a Financial Institution Partner
}

Launched in 2006, over 8,700 residential energy upgrades have been completed through Austin Energy's Home Performance with Energy Star (HPwES) program. ${ }^{1}$ The program's lending partner, Velocity Credit Union (VCU) has originated almost 1,800 loans, totaling approximately \$12.5 million. Residential energy efficiency loans are typically small, and expensive to originate and service relative to larger financing products. National lenders have been hesitant to deliver attractive loan products to this small, but growing, residential market. In response, energy efficiency programs have found ways to partner with local and regional banks, credit unions, community development finance institutions (CDFIs) and co-ops to deliver energy efficiency financing to homeowners. VCU's experience with the Austin Energy HPwES program highlights the potential benefits of energy efficiency programs to a lending partner.

\section{Encouraging Home Energy Upgrades in Austin}

The city of Austin, Texas has been operating residential energy efficiency programs since 1982. In 2006, Austin Energy (AE), the nation's ninth largest community-owned public utility, launched a Home Performance with Energy Star (HPwES) program. Over 8,700 energy upgrades have been completed through this initiative to date. HPwES participants may choose rebates of up to 20 percent of the upgrade's cost or low-interest unsecured financing through the program's partner, Velocity Credit Union. ${ }^{1}$ Austin Energy buys down the interest rate on these loans to between 0 and 6 percent depending on the

This is the second in a series of LBNL Clean Energy Program Policy Briefs. Using case studies, these working papers highlight emerging program models, important issues that new programs face, and how these issues are being addressed. The work described in this Policy Brief was funded by the Department of Energy Office of Energy Efficiency and Renewable Energy, Weatherization and Intergovernmental Program under Contract No. DE-AC0205CH11231. Please direct questions or comments to Mark Zimring (mzimring@lbl.gov).

\section{DISCLAIMER}

This document was prepared as an account of work sponsored by the United States Government. While this document is believed to contain correct information, neither the United States Government nor any agency thereof, nor the Regents of the University of California, nor any of their employees, makes any warranty, express or implied, or assumes any legal responsibility for the accuracy, completeness, or usefulness of any information, apparatus, product, or process disclosed, or represents that its use would not infringe privately owned rights. Reference herein to any specific commercial product, process, or service by its trade name, trademark, manufacturer, or otherwise, does not necessarily constitute or imply its endorsement, recommendation, or favoring by the United States Government or any agency thereof, or the Regents of the University of California. The views and opinions of authors expressed herein do not necessarily state or reflect those of the United States Government or any agency thereof or the Regents of the University of California.

\footnotetext{
${ }^{1}$ As part of its Better Buildings grant from the Department of Energy, Austin Energy recently ran the 'Best Offer Ever' promotion in which participants could receive both rebates and financing. Over 300 comprehensive energy upgrades are expected to be completed through this initiative. A DOE case study with more details on the 'Best Offer Ever' is forthcoming.
} 
comprehensiveness of the home energy upgrade, term of the loan and the customer's personal credit profile.

\section{Residential Energy Efficiency Financing Overview}

The upfront costs of residential energy efficiency improvements and poor access to capital are deterrents for many homeowners that want to invest in improving the efficiency of their existing homes. ${ }^{23}$ Residential energy efficiency loans are typically small $(\$ 5,000-\$ 10,000)$, making them expensive to originate and service relative to larger financing products. Lenders have been hesitant to provide low interest, long term financing that matches the expected savings from energy upgrades, and a secondary market for residential energy efficiency loans has not yet developed. ${ }^{4}$ Many energy efficiency program administrators have used American Recovery and Reinvestment Act (ARRA) grant funds to establish credit enhancements that incentivize private lenders to offer more attractive energy efficiency loan terms or to reduce the interest rates of existing loan products to customers through interest rate buy downs.

National lenders have, generally, not yet delivered attractive loan products to the market. Instead, ARRA-funded programs have partnered with local and regional banks, credit unions, community development finance institutions (CDFIs) and co-ops to deliver energy efficiency financing to homeowners. Velocity Credit Union's experience with Austin Energy's HPwES program highlights the benefits that lending partners may receive from participating in these programs.

\section{Austin Energy and Velocity Credit Union}

Since 2004, Velocity Credit Union (VCU) has partnered with Austin Energy to provide residential energy efficiency financing. ${ }^{5}$ VCU does not receive a credit enhancement, but Austin Energy buys down loan interest rates. Through AE's program, VCU has originated almost 1,800 loans, totaling approximately $\$ 12.5$ million of financing (see Table 1 for more details on loan terms).

Table 1. Austin Energy Home Performance with Energy Star Loan Terms Summary

\begin{tabular}{|c|c||}
\hline \multicolumn{2}{|c||}{ Austin HPwES Loan Terms Summary } \\
\hline Eligible Properties & Single-family homes \& duplexes \\
\hline Minimum FICO Score & None \\
\hline Maximum Debt-to-Income Ratio & 50 percent \\
\hline Customer Interest Rates & $\begin{array}{c}\text { 0 to 6 percent depending on credit profile, } \\
\text { measures installed, and loan length* }\end{array}$ \\
\hline Loan Length & 3 to10 years* \\
\hline Min/Max Loan Size & \$1,500 to \$11,000 \\
\hline Closing Costs & None \\
\hline
\end{tabular}

\footnotetext{
${ }^{2}$ Bracken Hendricks, Benjamin Goldstein, Reid Detchon and Kurt Shickman “Rebuilding America” August 2009. Center for American Progress and Energy Future Coalition

${ }^{3}$ The availability of attractive financing, on its own, is not a silver bullet to increasing demand for residential energy efficiency upgrades. Most existing financing programs reach less than .5 percent of their target population each year.

${ }^{4}$ The development of secondary markets is likely to lead to the availability of less costly capital for energy efficiency loans. To date, insufficient loan volume has been originated to establish these markets.

${ }^{5}$ Starting in 2006, these loans were offered as part of AE's HPwES program.
} 
*Loan length was temporarily reduced to 5 years and all interest rates were 0 percent under Austin Energy's temporary 'Best Offer Ever' initiative.

VCU indicated that serving as the program's financing partner provides several compelling benefits that help to offset program reporting requirements and the administrative burden of low-dollar loan origination and servicing:

\section{Low cost of customer acquisition}

For VCU, low cost access to new customers is the most attractive element of participating in Austin Energy's program. Mike Fisher, VCU's loan program manager, notes that VCU's energy efficiency loan approval rate is 82 percent, significantly higher than the credit union's 52 percent average approval rate for other product offerings. This high approval rate may be because many energy efficiency early adopters tend to be more affluent than the average American. Moreover, once loan applications are approved, AE customers are three times more likely to take the loan than is typical for other VCU financing products (63 percent of applicants accept approved AE loans compared to 20 percent for other VCU products). Because both a higher percentage of applications are being approved through the Austin Energy loan program and more of these loans are being funded, VCU's administrative costs per loan originated are lower than for its typical product offerings. In addition, because Austin Energy is so involved in the energy upgrade process, instead of having to track down the information necessary to close loans from customers and contractors, VCU relies heavily on the utility for any missing information — which helps to avoid delays. Fisher points out that, "With Austin Energy, we know who to go to and they usually have what we need."

Another program benefit is that Austin Energy, participating contractors, and other stakeholders actively market the HPwES program to Austin homeowners. This reduces VCU's advertising costs as potential customers often proactively seek out the credit union. Ultimately, these low advertising and origination costs benefit both VCU and Austin Energy-VCU gets a low-cost channel for customer acquisition and, in turn, discounts its base interest rates on the energy efficiency loan offering by up to 20 percent, reducing Austin Energy’s per-loan interest rate buy down expense.

\section{An attractive offer drives additional sales}

While AE funds interest rate buy downs to as low as 0 percent, Mike Fisher says that VCU gets a major reputational benefit as borrowers perceive VCU as a low-interest lender. Offering a low interest product distinguishes VCU from its peers in an otherwise very competitive lending market, and the credit union leads with this product when marketing to potential new credit union members. ${ }^{6}$

For credit unions, cross selling additional financing products to new members is an important, and challenging, business growth strategy. Typically, VCU turns just 3 percent of its loans to new customers into sales of additional products (97 percent of new customers take out just a single loan). Through the Austin Energy loan program, VCU's conversion rate is three times higher. Fisher believes that this high conversion rate is attributable to both the positive reputational impact from the low-interest AE loans and

\footnotetext{
${ }^{6}$ Many Recovery Act grantees are funding credit enhancements such as loan loss reserves instead of interest rate buy downs. By reducing lender risks, these credit enhancements help to lower interest rates to borrowers.
} 
his ability to educate customers that are otherwise unfamiliar with credit unions about the benefits of membership.

Buying down interest rates is an expensive proposition for energy efficiency programs that can cost as much as 10 percent or more of the overall energy upgrade cost (depending on the size of the loan, the reduction in interest rate, and the term of the loan). ${ }^{7}$ For many Recovery Act grantees, this level of spending is not possible or sustainable. Austin Energy plans to use some of its \$10 million Department of Energy BetterBuildings grant to test the efficacy of different incentive offers in driving demand for home energy upgrades. ${ }^{8}$ While we still have much to learn about the best way to allocate limited program budgets, Austin's experience suggests that these buy downs may be a valuable tool in attracting potential lending partners.

\section{Free contractor due diligence}

VCU is viewed as an extension of Austin Energy's program, so the quality of contractor work, good or bad, reflects on the lender's reputation. The lending community is often hesitant to provide home improvement loans due to contractor performance concerns. Austin Energy has extensive contractor training and quality assurance processes in place and this due diligence provides VCU with a high level of confidence, at no cost, in the quality of home energy improvements that are being funded.

\section{A responsive program administrator}

Through the AE loan program, VCU pre-qualifies applicants for financing and then funds loans once the borrowers' home energy upgrades are completed. During Austin Energy’s ‘Best Offer Ever’ promotion, contractor and inspector capacity was maxed out and a backlog of both unfinished projects and completed projects awaiting final inspection was building. ${ }^{9}$ Contractor and inspector delays caused a number of homeowners' loan pre-qualification funding windows to close, forcing VCU to redraft documents for a number of loan applicants, a burdensome and costly process for both customers and the credit union. Austin Energy responded quickly to minimize the problem. AE added additional inspection capacity and began sending out weekly notices to contractors to keep them informed of when their customers' loan pre-qualifications would expire so that they could prioritize those jobs in their work scheduling. Mike Fisher pointed out that, "Energy efficiency programs are inherently complex, and challenges will inevitably impact financing partners. From VCU's perspective, it is important to trust that the program administrator is focused on making sure the program works for its lending partner.”

\section{Next Steps}

Austin Energy was awarded a \$10 million BetterBuildings grant in 2010. The utility released a new RFP for financing partners in February 2011 as it plans to use some of its BetterBuildings monies to expand its financing offerings. For more information on Austin Energy's Home Performance with Energy Star, visit Austin Energy's website.

\footnotetext{
${ }_{8}^{7}$ Over the past 12 months, Austin Energy spent approximately $\$ 980$ per loan originated on interest rate buy downs.

8 There is very limited evidence on the role that low-interest financing plays in driving demand for home energy upgrades or whether monies allocated to interest rate buy downs might be better spent on direct rebates or other initiatives to motivate customer action.

${ }^{9}$ As a quality assurance measure, loans cannot be funded until AE has conducted a final inspection of completed projects.
} 